Abstracta Iranica

Revue bibliographique pour le domaine irano-aryen

Volume 40-41 | 2019

Comptes rendus des publications de 2017-2018

\title{
Daniel T. Potts, "The Sale and Lease of Vineyards in Media Atropatene"
}

\section{Leonardo Gregoratti}

\section{Q OpenEdition \\ 1 Journals}

\section{Electronic version}

URL: http://journals.openedition.org/abstractairanica/49682

DOI: 10.4000/abstractairanica.49682

ISBN: 1961-960X

ISSN: 1961-960X

Publisher:

CNRS (UMR 7528 Mondes iraniens et indiens), Éditions de l'IFRI

Electronic reference

Leonardo Gregoratti, "Daniel T. Potts, "The Sale and Lease of Vineyards in Media Atropatene"', Abstracta Iranica [Online], Volume 40-41 | 2019, document 32, Online since 30 October 2019, connection on 20 April 2021. URL: http://journals.openedition.org/abstractairanica/49682 ; DOI: https://doi.org/10.4000/abstractairanica.49682

This text was automatically generated on 20 April 2021.

Tous droits réservés 


\title{
Daniel T. Potts, "The Sale and Lease of Vineyards in Media Atropatene"
}

\author{
Leonardo Gregoratti
}

\section{REFERENCES}

Daniel T. Potts, "The Sale and Lease of Vineyards in Media Atropatene" in Pavel Avetisyan, Yervand Grekyan (eds.). Bridging times and spaces. Papers in ancient Near Eastern, Mediterranean and Armenian Studies. Honouring Gregory E. Areshian on the occasion of his sixty-fifth birthday. Oxford: Archaeopress, 2017, p. 349-356

1 D.P. presents some scattered observations concerning the so-called Avroman documents, a series of texts written on leather, which have not obtained from modern scholars the attention they deserve. Found in 1909, in Iranian Kurdistan, the three documents, two written in Greek and the third in Parthian, concern the sale of vineyards between local people and cover more than 140 years, the oldest being dated to the $88 \mathrm{BC}$, the most recent to $53 \mathrm{AD}$. The two documents in Greek are written twice. One version according to the first scholars, who examined them, was rolled up and sealed to avoid any modification of the contents. The other one was open to allow reading. This habit of drafting documents in two copies was considered an import of Greek archival organization due to similar double documents found in Ptolemaic Egypt. The author points out that a near eastern origin dating back to the Assyrian past of those same regions is much more probable. Potts goes on dealing summarily with the traces of viticulture in north-west Iran from the most ancient archaeological findings to 19th-century reports. The presence of texts in Greek and references to Greek culture in a rural region of the Parthian empire should not be a surprise considering that areas of strong Greek culture were present in the western cities and the Parthians were Hellenized even though mostly in a superficial way. A final remark, somehow imposed by the nature of the collected volume, is reserved to the link with Armenia, a kingdom with strong connection with that of Media, where the documents have been found: in a 
document one of the wives of Arsaces, the Parthian king Gotarzes I, is a daughter of Tigranes, the famous monarch of Armenia.

\section{AUTHORS}

\section{LEONARDO GREGORATTI}

Durham University 